\title{
UPAYA MENINGKATKAN MOTIVASI BELAJAR PKN SISWA KELAS VII.4 MELALUI PENERAPAN MODE PEMBELAJARAN KOOPERATIF DENGAN TEKNIK KELILING KELAS DI SMP NEGERI 21 PEKANBARU
}

\author{
Lamria Sihombing \\ SMP Negeri 21 Pekanbaru \\ e-mail: lamria1963@gmail.com
}

\begin{abstract}
This devotional activity is downstream of the research background of the low motivation of learning Civics students Class VII.4 SMP Negeri 21 Pekanbaru. This study aims to improve the motivation of learning Civics through the implementation of cooperative learning model of classroom student technique Class VII.4 Junior High School 21 Pekanbaru, which is held for 1 month. As Subjects in this study are students of Class VII.4 SMP Negeri 21 Pekanbaru. The number of students who made the subject of research as many as 40 students. The form of research is classroom action research. The instrument of this research consists of learning motivation instruments and data collection instruments in the form of observation sheet of teacher activity and student activity.

Based on the results of the analysis and the previous discussion can be concluded that with the implementation of cooperative learning methods classroom techniques can improve the Motivation Learning Civics students Class VII.4 in SMP Negeri 21 Pekanbaru. Where from the result of observation to 6 indicators of student motivation in the first cycle show that student's learning motivation is still relatively low with score 123, with a mean percentage of motivation learn equally to $50.0 \%$. While on the second cycle reached a score of 191 with very high criteria and the average percentage of student learning motivation of $77.6 \%$. This success is due to the use of cooperative learning methods of classroom techniques that enhance social interaction between students and between teachers and students, as well as the atmosphere in the classroom. Cooperative learning techniques around the classroom also make students feel having fun or excited and eager to learn. With these conditions will increase student acceptance and motivation to learn
\end{abstract}

Keywords: cooperative learning classroom technique, learning motivation Pkn

\section{Abstrak}

Kegiatan Pengabdian ini merupakan hilirisasi dari Penelitian yang dilatarbelakangi oleh rendahnya motivasi belajar PKn siswa Kelas VII.4 SMP Negeri 21 Pekanbaru. Penelitian ini bertujuan untuk meningkatkan motivasi belajar PKn melalui penerapan model pembelajaran kooperatif teknik keliling kelas siswa Kelas VII.4 SMP Negeri 21 Pekanbaru, yang dilaksanakan selama 1 bulan. Sebagai Subjek dalam Penelitian ini adalah siswa Kelas VII.4 SMP Negeri 21 Pekanbaru. Jumlah siswa yang dijadikan subjek penelitian sebanyak 40 orang siswa. Bentuk penelitian adalah penelitian tindakan kelas. Instrumen penelitian ini terdiri dari instrumen motivasi belajar dan instrumen pengumpulan data berupa lembar observasi aktivitas guru dan aktivitas siswa.

Berdasarkan hasil analisis dan pembahasan sebelumnya dapat disimpulkan bahwa dengan penerapan metode Pembelajaran Kooperatif teknik keliling kelas dapat meningkatkan Motivasi Belajar PKn siswa Kelas VII.4 di SMP Negeri 21 Pekanbaru. Dimana dari hasil observasi terhadap 6 indikator motivasi belajar siswa pada siklus pertama menunjukkan bahwa motivasi belajar siswa masih tergolong rendah dengan Skor 123, dengan rata-rata persentase motivasi belajar sebesar 50.0\%. Sedangkan pada siklus II mencapai skor 191 dengan kriteria sangat tinggi dan persentase rata-rata motivasi belajar siswa sebesar 77,6\%. Keberhasilan ini disebabkan dengan menggunakan metode pembelajaran kooperatif teknik keliling kelas yang meningkatkan interaksi sosial antar siswa dan antara guru dengan siswa, serta suasana didalam kelas. Pembelajaran kooperatif teknik keliling 
kelas juga membuat siswa merasa having fun atau senang dan bersemangat dalam belajar. Dengan kondisi tersebut akan meningkatkan penerimaan siswa dan motivasi belajarnya

Kata kunci : pembelajaran kooperatif teknik keliling kelas, motivasi belajar Pkn

\section{PENDAHULUAN}

Tugas dan peranan guru sebagai pendidik profesional sesungguhnya sangat kompleks, tidak terbatas pada saat berlangsungnya interaksi edukatif di dalam kelas, yang lazim disebut proses belajar mengajar. Guru juga bertugas sebagai administrator, evaluator, konselor, dan lain-lain sesuai dengan sepuluh kompetensi (kemampuan) yang dimilikinya. Namun sebagai inti dari kegiatan pendidikan sekolah, proses belajar mengajar sangat menentukan hasil belajar yang akan dicapai oleh siswa.

Kondisi di atas sesuai dengan pendapat Sobel dan Maletsky (2004:12) bahwa murid-murid akan belajar secara efektif jika mereka benar-benar tertarik terhadap pelajarannya. Akan tetapi sulit bagi guru-guru untuk menemukan persediaan gagasannya tentang menyampaikannya secara menarik. Banyak guru yang terlibat dalam rutinitas menyampaikan materi pelajaran sehingga mereka kehilangan waktu dan energi untuk mencari hal-hal yang memotivasi muridnya.

Terjadinya perbedaan reaksi ataupun aktivitas dalam belajar seperti yang digambarkan di atas dapat dijelaskan melalui pembahasan tentang perbedaan motivasi. Sebagaimana dikemukakan oleh Prayitno, Elida (1989:8) bahwa motivasi dalam belajar tidak saja merupakan suatu energi yang menggerakkan siswa untuk belajar, tetapi juga suatu yang menggerakkan aktivitas siswa kepada tujuan belajar.

Menurut Anderson dalam Prayitno, Elida (1989:8), mengemukakan bahwa: Motivasi dalam belajar dapat dilihat dari karakterisitik tingkah laku siswa yang menyangkut minat, ketajaman perhatian, konsentrasi dan ketekunan. Siswa yang memiliki motivasi yang tinggi dalam belajar menampakkan minat yang besar dan perhatian yang penuh terhadap tugas-tugas belajar. Mereka memusatkan sebanyak mungkin energi fisik maupun psikis terhadap kegiatan, tanpa mengenal perasaan bosan, apalagi menyerah.

Dari hasil pengamatan dan pengalaman penulis di SMP Negeri 21 Pekanbaru ditemui gejalagejala atau fenomena khususnya pada pelajaran PKn yaitu sebagai berikut: a) Masih sedikit proses belajar mengajar yang mengacu pada keterlibatan siswa atau keaktivan siswa. Hal ini dapat dilihat dari kurang bergairahnya mereka dalam belajar, dan kurang keinginannya untuk bertanya pada guru, b) Proses belajar mengajar tidak memancing siswa untuk terlibat secara aktif, hal ini tampak dari kegiatan anak yang sibuk dengan kegiatannya masing-masing, c) Pembelajaran hanya menekankan pada segi kognitif saja kurang melibatkan siswa, sehingga siswa kurang mandiri.

Dari fenomena-fenomena atau gejala-gejala tersebut di atas, terlihat bahwa pembelajaran PKn kurang menarik perhatian siswa dan terkesan membosankan sehingga motivasi belajar anak terhadap pelajaran PKn cenderung rendah. Rendahnya motivasi belajar siswa menurut analisa penulis dipengaruhi oleh cara belajar yang kurang melibatkan siswa dan terkesan monoton. Guru cenderung menyampaikan materi pelajaran dengan ceramah, pembelajaran berkelompok, namun hanya siswa yang tergolong pintar saja yang yang aktif.

Peneliti telah berupaya untuk melakukan upaya untuk memperbaiki hasil pembelajaran PKn seperti dengan membuat tugas yang harus dikerjakan siswa di sekolah maupun di rumah, maupun belajar kelompok namun belum memberikan hasil yang optimal. Upaya yang dilakukan belum mampu meningkatkan nilai ketuntasan belajar siswa.

Oleh sebab itu peneliti tertarik ingin melakukan suatu penelitian tindakan sebagai upaya dalam melakukan perbaikan terhadap pembelajaran dengan judul " Upaya Meningkatkan Motivasi Belajar PKn Siswa Kelas VII.4 Melalui Penerapan Model Pembelajaran Kooperatif Dengan Teknik Keliling Kelas di SMP Negeri 21 Pekanbaru"

\section{METODE}


Penelitian tindakan kelas ini dilaksanakan di Kelas VII.4 di SMP Negeri 21 Pekanbaru dengan jumlah siswa sebanyak 41 orang..

Penelitian ini terdiri dari dua variabel yaitu:

(1) Pembelajaran Kooperatif teknik keliling kelas merupakan variabel yang mempengaruhi. Tipe ini ditentukan dengan indikator: 1) membagi kelompok belajar secara heterogen, 2) menjayikan materi secara ringkas, 3) memberikan tugas secara individu, 3) membimbing diskusi kelompok, 4) Guru membantu kelompok diskusi dan meminta kelompok untuk memamerkan hasil kerjanya pada kelompok lain, 5) Masing-masing kelompok berjalan keliling kelas dan mengamati hasil karya kelompok-kelompok lain, 6) memberikan kesempatan kepada siswa memberikan pertanyaan ataupun memberikan tanggapan, 7) Guru memberikan penguatan dan mengajak siswa menyimpulkan materi yang sedang dipelajari.

(2) Motivasi belajar merupakan variabel yang dipengaruhi merupakan kekuatan mental yang mendorong terjadinya proses belajar. Adanya motivasi belajar dalam diri siswa ditunjukkan oleh indikator: 1) adanya peningkatan aktivitas belajar, 2) adanya peningkatan upaya belajar, 3) adanya kegembiraan dalam belajar, 4) tidak mudah mengeluh, 5) tidak mudah putus asa, dan 6) belajar dengan serius.

\section{a. Perencanaan/persiapan} sebagai berikut:

Dalam tahap perencanaan atau persiapan tindakan ini, langkah-langkah yang dilakukan adalah

1) Menyusun rencana pembelajaran dan silabus dengan dengan menggunakan Penerapan Model Pembelajaran Kooperatif teknik keliling kelas.

2) Membuat lembar kerja dan menyusun lembar kerja siswa yang berisi langkah-langkah mengerjakan tugas dalam diskusi dengan menggunakan Penerapan Model Pembelajaran Kooperatif teknik keliling kelas

3) Menyiapkan format pengamatan proses pembelajaran yang terdiri dari situasi kegiatan belajar mengajar, keaktifan siswa dalam pembelajaran dan kemampuan siswa dalam menjawab dan atau mengajukan pertanyaan.

4) Menyusun daftar pertanyaan yang akan diajukan kepada siswa setelah kegiatan diskusi kelompok berakhir.

5) Menyusun alat evaluasi untuk mengukur peningkatan motivasi belajar siswa.

\section{b. Pelaksanaan Tindakan (Action)}

1) Membagi siswa dalam 9 kelompok dengan angota kelompok yang heterogen baik dari segi prestasi, jenis kelamin, dan suku, yang pembagian kelompoknya dilakukan guru secara acak.

2) Guru menyajikan pelajaran secara garis besar dan memberikan topik-topik penting dalam materi pelajaran.

3) Memberikan tugas secara individu,

4) Membimbing diskusi kelompok,

5) Guru membantu kelompok diskusi dan meminta kelompok untuk memamerkan hasil kerjanya pada kelompok lain,

6) Masing-masing kelompok berjalan keliling kelas dan mengamati hasil karya kelompokkelompok lain,

7) Memberikan kesempatan kepada siswa memberikan pertanyaan ataupun memberikan tanggapan,

8) Guru memberikan penguatan dan mengajak siswa menyimpulkan materi yang sedang dipelajari.

9) Guru kemudian mengumumkan kelompok yang menang, masing-masing team akan mendapat sertifikat atau hadiah apabila rata-rata skor memenuhi kriteria yang ditentukan. 


\section{c. Observasi}

Pengamatan atau observasi yang dilakukan dalam penelitian ini dilakukan oleh guru Kelas VII yang telah bersedia menjadi observer dalam penelitian ini dengan menggunakan format pengamatan yang telah disediakan. Aspek-aspek yang diamati antara lain:

a. Aktivitas guru dalam Model Pembelajaran Kooperatif teknik keliling kelas yang dilakukan dengan menggunakan lembar observasi aktivitas guru

b. Aktivitas siswa selama proses perbaikan pembelajaran dengan mengunakan Model Pembelajaran Kooperatif teknik keliling kelas yang dilakukan dengan menggunakan lembar observasi aktivitas siswa .

\section{d. Refleksi}

Setelah perbaikan pembelajaran dilaksanakan guru dan observer melakukan kerjasama dan menganalisa hasil dari proses pembelajaran yang dilaksanakan, sehingga diketahui keberhasilan dan kelemahan pembelajaran yang telah dilaksanakan.

Hasil dari analisa data tersebut dijadikan sebagai landasan untuk siklus berikutnya, sehingga antara siklus I dan siklus II ada kesinambungan dan diharapkan kelemahan pada siklus yang pertama dapat dijadikan sebagai dasar perbaikan pada siklus yang berikutnya.

\section{Teknik Pengumpulan Data}

Adapun data dalam penelitian ini adalah data yang dilakukan melalui lembar observasi, data yang diperlukan yaitu:

a. Data tentang penerapan Model Pembelajaran Kooperatif teknik keliling kelas, yaitu data tentang aktivitas siswa dan aktivitas guru dalam pembelajaran yang diperoleh melalui lembar observasi.

b. Data tentang motivasi belajar siswa dalam pembelajaran yang diperoleh melalui lembar observasi tentang motivasi belajar siswa.

Adapun indikator yang dipergunakan untuk mengetahui motivasi belajar siswa yaitu:

1) adanya peningkatan aktivitas belajar,

2) adanya peningkatan upaya belajar,

3) adanya kegembiraan dalam belajar,

4) tidak mudah mengeluh,

5) tidak mudah putus asa,

6) belajar dengan serius

Pengukuran motivasi belajar siswa, karena indikator motivasi adalah 6 , dengan pengukuran masing-masing 0 dan 1 berarti skor maksimal dan minimal adalah 246 (41 x 6) dan 0 . Menentukan 4 klasifikasi tingkat motivasi belajar siswa, dapat dihitung dengan cara:

a. Menentukan jumlah klasifikasi yang diinginkan, yaitu 4 klasifikasi yaitu sangat tinggi, tinggi, rendah, dan rendah sekali.

b. interval (I), yaitu: $\mathrm{I}=\underline{\text { Skor } \max -\text { Skor } \min }=\underline{246-0}=62$

c. Menentukan klasifikasi tingkat motivasi belajar siswa, yaitu:

Sangat tinggi, apabila $186-246$

Tinggi,

Rendah, apabila $124-185$

Sangat rendah, apabila $63-123$ apabila $0-62$

\section{HASIL DAN PEMBAHASAN}

Dari hasil observasi terhadap 6 indikator motivasi belajar siswa pada siklus pertama menunjukkan bahwa motivasi belajar siswa masih tergolong rendah dengan Skor 123, dengan rata-rata persentase motivasi belajar sebesar 50.0\%. sedangkan pada siklus II mencapai skor 191 dengan 
kriteria sangat tinggi dan persentase rata-rata motivasi belajar siswa sebesar 77,6\%. Hal ini disebabkan pengelolaan pembelajaran pada siklus I yang belum optimal pada beberapa aspek seperti dijelaskan dalam siklus I dan telah diperbaiki pada siklus II ini.

Perbandingan antara motivasi belajar pada Siklus I dan Siklus II secara jelas dapat dilihat pada Tabel berikut ini:

Tabel 1. Rekapitulasi Motivasi Belajar Siswa pada Siklus I dan Siklus II.

\begin{tabular}{|c|c|c|c|c|c|c|c|c|c|}
\hline \multirow{2}{*}{\multicolumn{2}{|c|}{ SIKLUS }} & \multicolumn{6}{|c|}{ MOTIVASI SISWA } & \multirow[t]{2}{*}{ Jumlah } & \multirow[b]{2}{*}{ Rata-rata } \\
\hline & & 1 & 2 & 3 & 4 & 5 & 6 & & \\
\hline \multirow[t]{2}{*}{ I } & Jumlah siswa & 26 & 18 & 27 & 17 & 16 & 19 & 123 & \multirow[b]{2}{*}{50.0} \\
\hline & Persentase (\%) & 63.4 & 43.9 & 65.9 & 41.5 & 39.0 & 46.3 & & \\
\hline \multirow[t]{2}{*}{ II } & Jumlah siswa & 33 & 30 & 36 & 30 & 32 & 30 & 191 & \multirow[b]{2}{*}{77.6} \\
\hline & Persentase (\%) & 80.5 & 73.2 & 87.8 & 73.2 & 78.0 & 73.2 & & \\
\hline
\end{tabular}

Perbandingan antara motivasi belajar antara siklus I dan siklus II, juga ditampilkan dalam bentuk diagram batang berikut ini:

Gambar 1. Histogram Motivasi Belajar Siklus I dan II

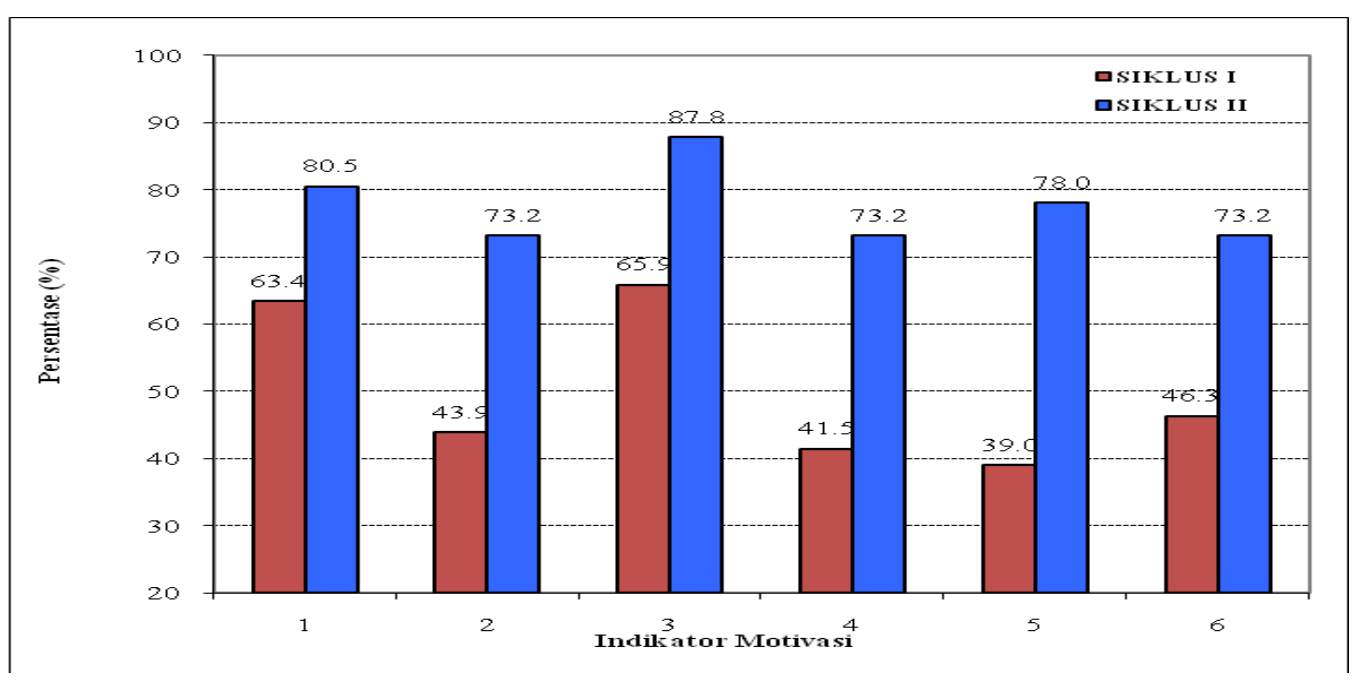

Keterangan aktivitas siswa:

1. Adanya peningkatan aktivitas belajar

2. Adanya Peningkatan upaya belajar

3. Adanya Gembira dalam belajar

4. Tak pernah mengeluh

5. Tak pernah putus asa

6. Belajar dengan serius

Berdasarkan Tabel 4.7. dan histogram di atas diketahui bahwa terjadinya peningkatan motivasi belajar siswa dari siklus I ke siklus II. Secara rinci diketahui bahwa pada indikator (1) Adanya peningkatan aktivitas belajar mengalami peningkatan sebesar $17,1 \%$ atau 7 orang siswa menjadi $80.5 \%$ atau 33 orang siswa pada siklus II. Pada indikator (2) Adanya peningkatan upaya belajar mengalami peningkatan sebesar $29.3 \%$ atau 12 orang siswa menjadi $73,2 \%$ atau 30 orang pada siklus II. Pada indikator (3) Adanya gembira dalam belajar pada siklus I mengalami peningkatan sebesar 9 orang atau $22 \%$ menjadi $87.8 \%$ atau 36 orang siswa pada siklus II. Pada indikator (4) tak pernah mengeluh mengalami peningkatan sebesar 13 orang atau $31.7 \%$ menjadi $73.2 \%$ atau 30 orang siswa pada siklus II. Pada indikator (5) tak pernah putus asa mengalami peningkatan sebesar 16 orang atau $39 \%$ menjadi $78 \%$ atau 32 orang siswa pada siklus II. Pada indikator terakhir (6) yaitu belajar dengan 
serius mengalami peningkatan sebesar 11 orang atau $26.8 \%$ menjadi $73,2 \%$ atau 30 orang siswa pada siklus II

Kelemahan-kelemahan penerapan pada siklus I tersebut setelah diperbaiki pada siklus II dan mencapai tingkat sempurna ternyata dapat meningkatkan motivasi belajar siswa. Melalui perbaikan proses pelaksanaan metode pembelajaran kooperatif teknik keliling kelas pada siklus II tersebut, motivasi belajar siklus II mencapai skor 191 dengan kriteria sangat tinggi, persentase rata-rata 6 indikator motivasi belajar sebesar $77.6 \%$.

Meningkatnya motivasi belajar siswa pada siklus II dibandingkan pada siklus I menunjukkan bahwa perbaikan pembelajaran yang dibawakan dapat memecahkan permasalahan yang dihadapi. Artinya, perencanaan pembelajaran yang dibuat sesuai untuk mengatasi permasalahan rendahnya motivasi belajar siswa yang terjadi di dalam kelas selama ini. Selanjutnya, adanya peningkatan motivasi belajar siswa pada mata pelajaran PKn dari sebelumnya ke siklus I dan kesiklus II menunjukkan bahwa penerapan metode pembelajaran kooperatif teknik keliling kelas dapat meningkatkan motivasi belajar PKn siswa Kelas VII.4 di SMP Negeri 21 Pekanbaru

Lie, Anita (2007:64) menyatakan bahwa model pembelajaran kooperatif keliling kelas adalah salah satu tipe atau model pembelajaran kooperatif yang mudah diterapkan, melibatkan aktivitas seluruh siswa tanpa harus ada perbedaan status dan dapat membangkitkan semangat belajar siswa dengan teknik memperlihatkan hasil kerja kelompok yang bertujuan memperlihatkan kemampuan kelompok masing masing untuk memancing kemampuan kerja kelompok lain. Dengan berjalan keliling kelas sambil mengamati hasil karya kelompok-kelompok lain siswa merasa having fun atau senang dan bersemangat dalam belajar.

Winkel (dalam Angkowo dan Kosasih, 2007:38) berpendapat bahwa faktor-faktor motivasi belajar dapat juga disebut faktor situasional seperti hubungan sistem sosial, status sosial siswa, interaksi sosial siswa, interaktis sosial antar siswa dan antara guru dengan siswa, serta suasana didalam kelas.

Dari hasil penelitian dan pembahasan seperti telah diuraikan di atas menjelaskan bahwa penerapan metode Pembelajaran Kooperatif teknik keliling kelas secara benar maka aktivitas siswa menjadi lebih aktif dan pada gilirannya motivasi belajar siswa menjadi lebih baik. Informasi data ini membuktikan bahwa hipotesis penelitian yang berbunyi " Dengan penerapan metode pembelajaran kooperatif teknik keliling kelas dapat meningkatkan Motivasi Belajar PKn siswa Kelas VII.4 di SMP Negeri 21 Pekanbaru "diterima".

\section{KESIMPULAN}

Berdasarkan hasil analisis dan pembahasan sebelumnya dapat disimpulkan bahwa dengan penerapan metode Pembelajaran Kooperatif teknik keliling kelas dapat meningkatkan Motivasi Belajar PKn siswa Kelas VII.4 di SMP Negeri 21 Pekanbaru. Dimana dari hasil observasi terhadap 6 indikator motivasi belajar siswa pada siklus pertama menunjukkan bahwa motivasi belajar siswa masih tergolong rendah dengan Skor 123, dengan rata-rata persentase motivasi belajar sebesar 50.0\%. Sedangkan pada siklus II mencapai skor 191 dengan kriteria sangat tinggi dan persentase rata-rata motivasi belajar siswa sebesar 77,6\%. Keberhasilan ini disebabkan dengan menggunakan metode pembelajaran kooperatif teknik keliling kelas yang meningkatkan interaksi sosial antar siswa dan antara guru dengan siswa, serta suasana didalam kelas. Pembelajaran kooperatif teknik keliling kelas juga membuat siswa merasa having fun atau senang dan bersemangat dalam belajar. Dengan kondisi tersebut akan meningkatkan penerimaan siswa dan motivasi belajarnya.

\section{SARAN}

Bertolak dari kesimpulan dan pembahasan hasil penelitian di atas, berkaitan dengan penerapan metode pembelajaran kooperatif teknik keliling kelas dapat meningkatkan motivasi Belajar PKn siswa Kelas VII.4 di SMP Negeri 21 Pekanbaru yang telah dilaksanakan, peneliti mengajukan beberapa saran, yaitu: 
1) Sebaiknya pelaksanaan metode pembelajaran kooperatif teknik keliling kelas lebih sering diterapkan agar dapat berjalan lebih baik dan lebih familiar.

2) Dalam penerapan metode pembelajaran kooperatif teknik keliling kelas, sebaiknya guru lebih mengontrol suasana kelas dan memilihkan kelompok serta tingkat kelas yang sesuai dengan kegiatan kerjasama siswa.

3) Guru lebih dapat memahami dan mengetahui bermacam ragam motivasi belajar siswa dan selalu mengingatkan siswa akan pentingnya percaya diri dan motivasi dalam belajar.

\section{DAFTAR PUSTAKA}

[1] Ahmadi, Abu dan Joko Tri Pasetya. 2005. Strategi Belajar Mengajar. Bandung: Pustaka Setia.

[2] Angkowo dan Kosasih. 2007.Optimalisasi Media Pembelajaran. Jakarta: Grasindo.

[3] Dimyati dan Mudjiono, 2002, Belajar dan Pembelajaran, Jakarta: Rineka Cipta,

[4] Etin Solihatin. 2007. Cooperative Learning Analisis Model Pembelajaran IPS. Jakarta: Bumi Aksara.

[5] Elida Prayitno.1989. Motivasi dalam belajar. Jakarta: P2LPTK

[6] Gimin, Dkk. 2005. Pedoman Penulisan Karya Ilmiah Mahasiswa. Pekanbaru: FKIP. UNRI. (tidak diterbitkan).

[7] Lie, Anita. 2007. Cooperative Learning. Jakarta: Raja Grafindo Persada

[8] Sanjaya, Wina. 2007. Strategi Pembelajaran Berorientasi Standar Proses Pendidikan. Jakarta: Kencana,

[9] Sardiman.2004. Interaksi dan Motivasi Belajar Mengajar. Jakarta: Rajawali pers

[10] Slavin, Robert E, 2008, Cooperative learning Teori, Riset dan Praktis. Bandung: Nusa Media.

[11] Sobel dan Maletsky. 2004. Pengajaran Sains di Sekolah Dasar. Jakarta: Gramedia 